\title{
A Sustainable Development Concept in the Light of the Kingdom of God
}

\author{
Dalia Matijević \\ Church of the Nazarene \\ daliamatijevic@gmail.com
}

UDK: 27-23:27-4:502.13

Original scientific paper

https://doi.org/10.32862/k.14.2.5

\section{Abstract}

In searching for answers about the actual relation between two apparently incompatible concepts: the Kingdom of God and the Sustainable Development (SD), we will try to put them side by side and use respective comparative findings, in order to see if they can work together and possibly benefit from each other. The aim is to better understand future perspectives that are opening for the church within the contemporary context.

The two concepts considered in this research, the Kingdom of God and SD, are never supposed to be separated. Although coming from different sources, using different languages, and springing out from different socio-political contexts, they tackle the same set of universal issues; both are eagerly anticipated, their fulfilment is of utmost importance, they both call for profound personal and communal transformation, both are powerfully creative and innovative, and both have the capacity to mobilize communities, peoples, and resources.

The intersections between the SD and the Kingdom of God create opportunities for the church to practice shalom and to nurture hesed in the world by encouraging inclusiveness, lobbing for social justice, carrying for the poor and marginalized, and extending love and compassion onto the whole of creation, without losing its genuine identity. Within the SD framework, the role of the church is to make sure that nobody is left behind. The church might be the best part of the SD practice by persistently insisting on the same universal set of Kingdom values no matter how circumstances are changing.

Key words: Kingdom of God, Sustainable Development (SD), personal and communal transformation, shalom, hesed 


\section{Introduction}

Our time is a time of multifaceted world crises. A crisis of life and capacity for peace, a crisis of the way of thinking which makes irreparable damage by encouraging consumeristic and relativistic worldviews, a crisis that brings hunger and poverty for millions in the midst of well-orchestrated efforts against massive misery, a crisis of climate change and nature's resources depletion, and a crisis of knowledge, health, and humanity. There is a deep need to reconsider and relearn from the life-giving concept of God's Kingdom.

The claim proposed in this article is that the Kingdom of God concept holds the essential structure, methodology, prerequisites, characteristics, and dynamics that should be strongly anticipated by any human-originated long-term development plan that strives to be meaningfully successful. The globally affirmed Sustainable Development (SD) framework, particularly represented through Agenda 2030, anticipates 17 sustainable development goals (SDG) and provides a valuable representative example. In this work, we will show how this global initiative has many important determinants of the Kingdom of God and as such, it needs to be taken seriously into account by the church, although it seems to be exclusively coming from the secular sphere. The intention is to confirm the crucial need of the church to affirm a fresh way of understanding its mission and reconsider what it means to be missional and thus meaningfully engaged in the dynamics of the contemporary world. Questions to be answered here are the following:

What is the relation between two concepts: the Kingdom of God and the SD?

In what sense are they different and in what sense are they similar? Are these two concepts supporting each other?

How is the SD concept relevant to the church?

How do we understand the mission of the church when considered through the lenses of the SD paradigm?

In order to search for answers, we will try to put two apparently incompatible concepts, the Kingdom of God and the SD, side by side, in order to see if they can work together and possibly benefit from each other. The purpose is to bring the Christian sphere and secular sphere into a meaningful correlation, especially in the context of exploring and finding new ways of honouring God coherently and holistically without compromising Christian identity. God has a plan of reconciling the whole created order back to himself and the church has a mission to participate in its implementation. In that context, I would like to see my church boldly affirming the whole world as "my parish."

1 John Wesley's famous words said when he was criticized for preaching outside of churches. 


\section{Understanding the terminology}

\subsubsection{Kingdom of God}

The Kingdom of God, or synonymous Matthew's Kingdom of Heaven, represented by Hebrew malkuth ${ }^{2}$ and Greek basileia tou theou, as well as other substantives of the same formations, is an abstract phrase that can refer to a territory, rule, kingship, sovereignty, etc. It represents God's attribute and the way of God's activity. Charles Dodd $(1961,24)$ explained it as a solid hope for the ultimate state of righteousness, "[the] underlying idea is that God's power becomes manifested in the world of human experience, meaning judgment will come on all that is wrong and blessing and deliverance will pour on all creation living in communion with God."

Two basic ways of interpretation were affirmed through the extended history of thinking about the Kingdom of God: eschatological and non-eschatological. The eschatological position, which was consistently affirmed by early church Fathers (e.g. Barnabas, Papias, Justin Martyr, Irenaeus, and Tertullian), was mostly elaborated by Albert Schweitzer who was persuaded that the teaching of Jesus was all together apocalyptical. This otherworldly aspect of the Kingdom of God, including the urgent expectation of God's imminent and ultimate vindication of his people, was inherited from early Judaism (Chilton 1984, 7-12). The non-eschatological position was mostly derived from Augustin's claim that the Church actually represents the Kingdom of God itself. Augustin and his inheritors were ignoring the biblical assumption about the Kingdom of God being primarily the supernatural activity of God. They were emphasizing the Kingdom's ethical principles and enjoy the idea of the Kingdom of God affirmed among humans (Chilton 1984, 13-22). Consequently, we still have a need for the meaningful, theological synthesis which would enable us to understand the Kingdom of God as an eschatological and futuristic reality which yet succeeds to powerfully permeate and shape our present reality.

According to Bruce Chilton $(1984,4)$, all evangelical Christians seem to agree on understanding Jesus' ministry primary purpose being announcing, preaching, and proclaiming the immanence of the Kingdom of God (Mt. 4:12-17; 4:23; 9:35; Mk. 1:14-15; Lk. 4:43; 8:1; 9:11). Though in some cases, incidental references to the Kingdom can leave us puzzled (e.g. Mk. 1:34 or Mt. 26:29), it does not imply that Jesus deliberately spoke about the Kingdom of God in an obscure manner. On the contrary, Jesus was talking about the idea everybody was familiar with.

2 Isaiah 52 is the most likely the reference from where the Gospel writers draw the idea of the Kingdom of God. Isaiah 52:7 'Your God reigns (malakh)' is closely connected to the idea of "peace, salvation, good news." 
The first century Jews were dreaming about the Kingdom of God, anticipating its fulfilment, and eagerly expecting its immediate coming (Chilton 1984, 6). It seems we are the ones who tend to miss the real context of the message, maybe because we do not dream about Thy Kingdom Come any more, at least not as an inextricably integral part of our mundane lives.

The Kingdom teaching of Jesus, as recorded in the Gospels, has reference to the future as well as to the present. Some of the future references seem to refer plainly to the forthcoming historical events while others resemble visionary apocalyptic forecasts. Present and future references are tightly intermingled and we can certainly agree with Dodd $(1961,36)$ that to disentangle them is not an easy task.

\section{Sustainable Development}

The Sustainable Development (SD) has been defined as the way of progressive development that meets the needs of the present generation without compromising the ability of future generations to meet their own needs. The concept of needs in this context goes beyond simple material needs and includes values, relationships, freedom to think, act, and participate, all amounting to sustainable living, morally, and spiritually. ${ }^{3}$ It arose from the apparent need of modern humans to deal with the complex set of problems, perspectives, values, and interests while trying to understand the best possible way forward for the human society.

Maybe the best way to understand the whole concept ${ }^{4}$ is to see it as an open "dialogue of values" and the practical way of encouraging people to learn progressively, to grow in capacity to think and re-consider traditional ways of being and doing, and to do the research for themselves in order to gain some new valuable perspectives on the growing problems of the modern world. The entire concept is about protecting natural environment and resources through the consistent affirmation of social justice and economic equity principles. It is actually about preserving and valuing life in its genuine wholeness. Therefore, and the same is applicable for the Kingdom of God, SD is only apparently anthropocentric. It is essentially bio-centric, although practical application can open some confusing issues

3 See: https://www.sciencedirect.com/topics/earth-and-planetary-sciences/sustainable-development

4 I keep using the SD term dynamically either as a paradigm - an overarching social phenomenon that set standards of being and thinking; a concept - an abstract idea or general notion that employs corresponding principles; a perspective - a point of view; a framework - an essential supporting structure that serves as a platform for developing plans and programs; and a set of goals - particular ways of practical application. 
due to taking various shapes and expressions within many different contexts. The term itself can also seam profoundly contradictory since development anticipates economic growth and sustainability means life and production within ecological boundaries (Blewitt 2008, 62). By bringing development and sustainability together, the world intentionally opens itself for progressive transformation.

Important determinant of the secular SD perspective, which is also affirmed by many Christian leaders, is the relationship between learning and managing knowledge and innovations. In that sense, transformational leadership, ${ }^{5}$ which has an ability to discern the need for constant personal and professional growth, has a crucial role in making the SD meaningful and alive (Blewitt 2008, 175176).

\section{Methodology, Problems, and Questions}

The intention of this article is to consider the Kingdom of God concept as it is presented in the Bible, but having a specific focus on its determinants for the integral social and economic development of the human society. In parallel, we will consider the SD framework and then use respective comparative findings to better understand future perspectives that are opening within the contemporary context. The assumption is that the UN Agenda 2030 of 17 SDGs cannot be practically fulfilled without taking the Kingdom of God concept seriously into account. The very idea of the Kingdom of God clearly affirms far more than the modern paradigm of SD. As such, it creates the way to a society of freedom, righteousness, equity, mutual accountability, practical ethics, and the rule of law.

The UN Agenda 2030 is being affirmed by the UN Member States as an effective solution to the problem of further development in the modern world, which seriously takes into account the need for equal involvement and cooperation of all states within the complex process of achieving social and economic sustainability for all. Its optimistic plan to meet 17 SDGs by 2030 represents a continuation of the process which was initiated at the Rio de Janeiro Earth Summit in 1992. In that sense, massive amounts of resources have been mobilized to develop a legislative, financial, institutional, and operational framework for joint action over the last 25 years. But despite these great efforts of the international community there still seems to be no real progress.

Sigurd Grindheim $(2018,35)$ puts her finger on the Biblical assumption that the Kingdom of God is not for everyone: "It is not only hard to enter, it is easy to be kicked out too" and this kind of claim opposes the SD concept which claims

5 The dynamic process that eventually brings profound change in people and the way they understand their circumstances. Transformational leadership involves an exceptional form of influence that moves followers to accomplish more than what is usually expected of them (Blewitt 2008, 175-176). 
to be universally inclusive. From the biblical standpoint, that claim is unrealistic and utopian, maybe because it is primarily a human and humanistic project. Glen Stassen and David Gushee $(2003,54)$ elaborate on the issue of the Kingdom dynamics being primarily relational instead of being transactional and the SD idea certainly tries to follow that path. Actually, the communal pathos of the SD resembles and resonates with Christian ethics rather well.

It is important to consider how the Kingdom of God concept crucially shapes us as faithful practicing Christians, but it seems almost equally important today to be able to adopt the SD framework without feeling jeopardized from compromising the genuine Christian set of priorities. Therefore, let us try to see how the SD concept is relevant for the church and what particular aspects of the Kingdom of God might be especially helpful for the church to see the SD framework worthy of its engagement.

\section{The Kingdom of God}

The Kingdom of God/Heaven stands at the very centre of the message of Jesus. It represents a dominant biblical metaphor, one that is paradoxically both the meta-centre and the mystery in Jesus' proclamation (Perrin 2019, 31). As Jeremy $\mathrm{R}$. Treat $(2019,17)$ eagerly claims, Jesus gave his followers many commands but there was only one thing he said for them to seek first, "Seek first the kingdom of God" (Mt. 6:33). And that one thing changes everything.

The term itself comes from a world of oriental monarchies, thus its original background is greatly different from the context of modern world democracies. Historically, it has been associated with a progressively redeemed society inspired by love, future transformation of this world, and apocalyptic hope for the next world (Dulling 1992, 4932). The term Kingdom of God, literally coming from the

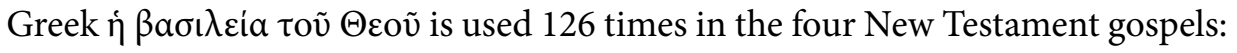
55 times in Matthew, 20 times in Mark, 46 times in Luke, 5 times in John, plus 8 times in Acts (Green 2013,468). The majority of these references to the Kingdom of God/Heaven assume basic equivalence to the related kingdom of the Father, kingdom of Jesus, and the kingdom of the Son of Man. In a sense of action, the Kingdom of God is most frequently entered (e.g. Mt. 5:20; Mk. 9:47; Lk. 18:17; In. 3:5), proclaimed (e.g. Mt. 4:23; 9:35; 10:7; 13:19; 24:14; etc.), desired (e.g. Mt. 6:33; Lk. 12:31), anticipated (e.g. Mk. 15:43, Lk. 23:51), possessed or received as a gift (e.g. Mt. 5:3; Lk. 12:32), granted (e.g. Lk. 22:29), inherited (e.g. Mt. 8:12; 25:34), or even taken from (e.g. Mt. 21:43) (Green 213, 468-479).

It has been argued that the Kingdom of God/Heaven is not primarily a spatial, territorial, political, or national notion; therefore, it should be translated as kingly rule, reign, or sovereignty rather than kingdom. When it comes to transla- 
tion, it is absolutely certain that the political, economic, and social dimensions of ancient oriental kingship must not be neglected. Many scholars have noted that the English phrase "kingdom of God" does not do justice to the New Testament Greek term since it connotes a physical space, place, or location, whereas the Greek one can refer to an action (e.g. the phenomenon of God ruling). ${ }^{6}$ In some cases Jesus does seem to be referring to a location (Mk. 14:25; Lk. 13:28), but in other cases He seems to speak of something more experiential (e.g. Matthew 6:33). When Jesus responds to the crucified thief: "Today, you will be with me in Paradise" (Lk. 23:43 NRSV), He refers to a realm beyond death. In John's Gospel, however, entering the Kingdom seems to be a present possibility (3:3-5) (Powell $2011,690)$. It is obvious we should not make the particular texts the key to the rest. Dale C. Allison Jr. $(2010,22)$ rightly warns us we should be able to avoid the temptation to flatten the data and to make the particular term referring consistently to the same thing. This is the case when one meaning does not necessarily exclude others. The term, in fact, is polysemous.

The Kingdom of God originates with God, draws its character from God, and precedes any human response. Thus it supports another important Christian theological concept that is rooted in Arminian/Wesleyan theology - prevenient grace $^{7}$ that adds to the sense of God being actively and dynamically involved in human life. Entering the Kingdom can have a meaning of entering space or place, but also sphere or experience of identification and/or participation. For Bruce Chilton, the Kingdom of God is above all else "God's activity in the world" that has a capacity to bring profound change.

But what does the Kingdom of God really look like? We read it is like a sower who goes forth to sow, filled with hope and anticipation, it is like a costly pearl awaiting to be appreciated, and it is like a tiny mustard seed having immense growth capacity (Mt. 13; Mk. 4; Lk. 8). We can certainly relate to these images and symbolism of understanding true values that only grow by time if rightly nurtured and appreciated. How does one enter and participate? Do we need to sell everything we have and give it to the poor, or do we need more to step back and become innocent, uncorrupted, and straight forward like a little child? Yes and yes. But there is even more. Is it important? Absolutely! Jesus says it would be better to mutilate ourselves than not to get in at all (Mt. 5:30; Mk. 9:43 NRSV).

6 Author's native language, Croatian, use the whole phrase "Kingdom of God" for the unique physical and spiritual sphere where God reigns sovereignly and His sovereignty powerfully permeates all aspects of being and doing.

7 Divine grace that precedes any human decision and/or action. God's grace enables, but does not ensure, personal acceptance of the gift of salvation. 


\section{Kingdom of God in the Old Testament}

The expression of the Kingdom of Heaven (Hebrew malkût šămayim) is not found in the Old Testament. However, there are many passages which refer to YHWH as a king indicating that God was imagined as the reigning king over Israel, all peoples, and nature. Many Biblical passages affirm that God rules over the creation, cares for people and other creatures, and brings about his divine purposes through them or on their behalf (e.g. Job 38-39; Ps. 104; 145; 147; Is. 45:1-13; Dan. 4:17; Jn. 1-4). It is also affirmed that God reigns in history over the affairs of Israel and other nations, especially in Psalms (e.g. 22:27-28; 47; 95-99) and Daniel $(4: 3,34-35)$. But God's reign also takes the form of judgment against Israel, Judah, or other nations (e.g., Jer. 1-11; Ez. 12-16; Amos 1:3-4:13) (Powell 2011, 689).

It is recognized that other forces are at work, preventing the fulfilment of God's purposes, most notably the perversity of God's own people (e.g., Is. 1; 3; 5; Jer. 2-8; Hos. 4-10; Amos 2:26-6:13; 8:4-7) and hostile enemy nations (e.g., Is. 13:1-19:15; Amos 1:3-2:3). Fate and chance are other factors (Eccles. 9:11-12). Thus, the Hebrew prophetic writings often look forward to a future time when God's rule or reign will be established on earth (e.g., Obad. 21; Hag. 2:21-23; Zech. 14:9). The new era is seen as one in which all nations will live at peace, acknowledging the Lord as their sovereign (e.g. Is. 2:2-4; 19:19-24; Mic. 4:1-3; cf. Zech. 14:16-19) and in some others, the new era will be one of peace and blessing for all creation (e.g. Is. 11:6-9; 65:17-25; Hos. 2:18; cf. Ez. 34:25-28). Therefore, although the exact phrase of the Kingdom of God is missing from the Old Testament, the idea itself, bearing strong eschatological and social significance, is very much present even widespread within the entire Hebrew Scriptures.

\section{Kingdom of God in the New Testament}

Jesus did not invent a new concept but he adopted an already existing, commonly understood idea of God's rule. Its scriptural affirmations are especially present in Psalms (Lord as a king exercises his royal sovereignty over the whole cosmos), Chronicles (Yahweh's reign is directly associated with the Davidic dynasty and Israel's worship), Daniel (God's reign is universal and everlasting), and other prophets, especially with Isaiah's anticipation of the end of exile and restoration of Israel through proclamation of the good news as peace and salvation (e.g. Is. 44:1-6) (Green 2011, 471).

Mark introduces a specific kind of the time tension: "The Kingdom of God is at hand" (or "has drawn near," 1:15 NRSV). The perfect tense in the Greek verb engiken refers to the past with present implications; yet, the future is implied as the Kingdom is not yet present with full apocalyptic power (same in Mk. 9:1; 14:25; 15:43) (Dulling 1992, 4942). This time-tension also corresponds to the Kingdoms presence as mysteriously hidden, incomprehensible to outsiders, such as religious 
authorities, but revealed to insiders (4:11). Another six Kingdom sayings in the central section $(9: 47 ; 10: 14,15 ; 10: 23,24,25)$, provide vivid illustrations of what kind of spiritual posture is needed to enter the Kingdom (being sinless, innocent like a child, free from material bondages). The Law, being understood as love of God and neighbor (Mk. 12:34), provide an added ethical value. To summarize, Mark introduces Kingdom sayings that all encompass clear eschatological (9:1; 14:25), Christological (1:15), and communal aspects (4:11) (Dulling 1992, 4942-3).

Matthew puts a special emphasis on preaching the gospel of the Kingdom. Jesus is predominantly a preacher and teacher of the gospel of the Kingdom (10:7; $28: 20)$, but the Kingdom itself also testifies about Jesus $(24: 14 ; 26: 13)$. It is anticipated in the present which flows from the past and overflows into the future. Therefore, it is temporal in being eschatological and Christological but it is also spatial since it draws near with Jesus. It is also ethical since the prerequisites for entering are rooted in ethics, having Jesus and John as models (Dulling 1992, 4944-5). The most Jewish of all four canonical Gospels uniquely uses the phrase "Kingdom of Heaven," probably recalling Daniel 2-7, which affirms the crucial difference between earthly and heavenly kingdoms. Being the only evangelist using the term ekklesia, Matthew presses the issue of relationship between the heavenly Kingdom and the Church (16:18-19) (Green 2011, 6571).

Luke and the book of Acts affirm the crucial need to keep proclaiming the Kingdom and living its principles, as Jesus lived them out on a daily basis. Still the emphasis is on many tribulations/persecutions that evokes and leads to compassionate concern for political, social, and economic realities of Christian life, especially for women, the poor, the sick, the imprisoned, and the generally marginalized. Luke is concerned with the politics of the Kingdom of God and interested in nature and distribution of power. Politics of the Kingdom refuses to enter the political game on Roman terms and instead sets out commitments to the needy and poor (Green 2013, 6574).

Within Johannine literature, there are 15 direct references and one indirect reference to Jesus as King, though most of them have a questioning or ironic sense. In John 18:36, Jesus responds to Pilate's question about his political status as a king, "My kingdom is not from this world" (NRSV) and this typically Johannine viewpoint may simply reflect a Johannine otherworldly sect attitude, but it certainly shapes our modern view on the Kingdom as the realm not having anything in common with the worldly business (Dulling 1992, 4948). Royal symbolism pervades the Book of Revelation and the heavenly Jerusalem (21:1-22:5) has been equated with the cosmic Kingdom of God (Dulling 1992, 4957).

Paul points to a tension between the present, anticipatory Kingdom of Christ/ God and the future apocalyptic consummation of the Kingdom of God at the end. Since the contexts often imply baptism, there is an attitude among scholars that 
Paul was probably trying to remould baptismal traditions (Dulling 1992, 4955-6).

Some scholarly concerns were related to the question of to what extent Jesus' proclamation of God's Kingdom actually represented a political statement and what possible political implications could be affirmed in that context? Richard A. Horsley claims that Jesus' call to covenant renewal was inseparable from his prophetic denouncement of Roman imperial rule (Green 2013, 6565). Jesus was lobbing for God's restoration in the economic, social, and political sphere, and not exclusively in the spiritual, ethereal, or religious sphere. However, in the midst of the harsh reality of the Second Temple Judaism, a proclamation of the Kingdom eventually moved to more ethereal spheres, and consequently, eschatological perspectives became more emphasized.

\section{The Kingdom of God and Mission}

If Michael Barram $(2007,44)$ is right when he invites for a missional reading of the Bible, then we should be able to discern the Kingdom of God concept as dynamical, coherent, and progressively expanding the missio Dei that essentially shapes the whole world including the holistic mission of the Church. The mission of the Church is thus tightly interconnected with/into the missio Dei and therefore totally incompatible with traditional reductionism and narrowness. The Kingdom of God spirals out into the world with a purpose to permeate the whole creation in myriad ways of reconciliation, and the church needs to respond centrifugally in finding her way right into the bull's eye. The biblical story does not move toward the destruction of the world and our own rescue to heaven. It culminates in the restoration of the entire creation to its original goodness.

There are some particular aspects of the Kingdom of God that might be helpful for the church to see the SD framework worthy of engagement. The most important is shalom (Greek eip门i $\eta$ usually translated as peace), the comprehensive Old Testament concept that can be described either as the absence of conflict, chaos, oppression, and broken relations, but also and moreover as the affirmation of wholeness, reconciliation, goodness, justice, wellbeing, and the flourishing of creation. Shalom is thus not a mere state of affairs but dynamic, progressive, creative, innovative, multiplying, and centrifugal power of goodness and well-being. It takes transformation from the default human state of conflict and restlessness to something that the prophet Isaiah masterfully brings us as the complex image of a new kind of human plight that is primarily relational and specifically covenantal, since it is brought forth by God (Is. 2:1-4) (Gorman 2016, 146-147).

The New Testament does not tell much about peace and Gorman finds the consequence of the peace being underrepresented in the New Testament texts being devastating for the life and mission of the Christian church (Gorman 2016, 144-145). "Blessed are the peacemakers, for they will be called children of God" (Mt. 5:9 NRSV) has been neglected and abused too many times during human 
history. Paul sees peace as an obvious task and practice of ecclesia, being closely interconnected with love and justice. He wants his communities to practice peace-making as a proactive way of life, and not only as a sort of apologia in the form of reactionary measures (Gorman 2016, 166). Christ-shaped or cruciform shalom should be (urgently) practiced always and everywhere.

A proper kind of solidarity represented by the Biblical concept of loving-kindness or steadfast love (Hebrew, hesed) which Walter Brueggemann $(2018,354)$ calls "tenacious solidarity," springs out of covenantal fidelity and thus creates "the deepest urge and hunger that are elemental to our humanness." The SD concept is all about keeping covenant among parties in the spirit of (political) goodwill but it still crucially misses the creative power and genuine inner logic of the Kingdom. The language of the Lord's Prayer is particularly important in pointing to God and His sovereign intervention. The simple fulfilment of the basic daily needs are presented here as a desired state: food for everybody, debts forgiven, and peaceful safety. These Kingdom principles of inclusiveness, participation, equity, and shared peace resonates well with the SD paradigm.

Through the concepts of shalom and hesed, the Kingdom of God powerfully permeates the SD idea as a basic presupposition of its realization as an essence of the human destiny which anticipates meaningful future perspectives and is a clear determinant of the universal and common success.

\section{UN Sustainable Development Goals}

\section{Historical background}

The SD concept arose from numerous twentieth-century environmental concerns and is derived from the Brundtland Report. ${ }^{8}$ Through the last three decades, the original idea of environmental protection and sound nature resource management being humanity's common and urgent need, progressively grew into a life-style changing paradigm. It is fuelled by the synchronized international community's effort and represented by the United Nations' effort that aims to build an inclusive and resilient future for the people and the planet. Although the original concept of broad environmental awareness eventually shifted more and

8 The World Commission on Environment and Development (WCED) published in 1987 a report entitled "Our common future." This document came to be known as Brundtland Report, named after the Commission's chairwoman Gro Harlem Brundtland, Norwegian medical doctor and politician. The Report boldly stated that critical global environmental problems were primarily the result of the enormous poverty of the South and the non-sustainable patterns of consumption and production in the North. See: https://sustainabledevelopment.un.org/content/documents/5987our-common-future.pdf. 
more into the sphere of economic and social development, it is still consistently focused on harmonizing between three tightly interconnected core elements considered to be crucial for the well-being of the humanity and creation in total: economic growth, social inclusion, and environmental protection.

From the time of the disturbing Brundtland Report's insight into the gloomy future of humanity, several crucial steps were undertaken by the international community on its joint way to the contemporary 2030 Agenda which anticipates the fulfilment of 17 SDGs. One of the first steps was the UN Conference on Environment and Development, so-called Earth Summit organized in 1992 in Rio de Janeiro, where three key international conventions ${ }^{9}$ were adopted to be implemented by 178 UN members and tightly integrated within their national legislative frameworks. The Earth Charter was published as a sort of conclusion of this UN conference in which the building of a just, sustainable, and peaceful global society in the 21 st century was boldly outlined. The common hope arose from this high-level political gathering that the international community is willing and dedicated to invest all its abilities and capacities to contribute to the harmonious implementation of the SD objectives. ${ }^{10}$ Information, integration, and participation were recognized as the key building blocks and fundamental prerequisites of achievement.

World leaders came back together in 2000 at the UN Headquarters in New York to adopt the United Nations Millennium Declaration. They created a new global partnership in dedicating their countries and peoples to actively participate in reducing extreme poverty in the world. A series of time-bound targets have been set that have become known as the Millennium Development Goals (MDGs). ${ }^{11}$ The eight MDGs were targeted to be reached by 2015 and they have greatly galvanized unprecedented efforts to meet the needs of the poorest people of the world.

9 Convention represents a legal instrument that is internationally agreed and legally binding for its signatories. Three Rio Conventions adopted from the 1992 Earth Summit are 1. Convention on Biological Diversity, 2. UN Convention to Combat Desertification, and 3. UN Framework Convention on Climate Change. These conventions are intrinsically linked and they are operating in the same ecosystems while addressing interdependent issues. Their purpose is to contribute to the SD goals outlined in Agenda 21. See: https://www.cbd.int/rio.

10 These objectives were formulated in the Agenda 21 - an action plan for SD, signed by parties voluntarily committing themselves to the immediate application of SD principles at global and regional, at a national and local levels. See: https://sustainabledevelopment.un.org/content/ documents/Agenda21.pdf.

11 Millennium Development Goals were 1. Eradicate extreme poverty and hunger; 2. Achieve universal access to primary education; 3. Promote gender equality and empower women; 4. Reduce child mortality, 5. Improve maternal health; 6 . Combat diseases as HIV/AIDS, malaria, etc.; 7. Ensure environmental sustainability; 8. Build a global partnership for development. See: https://www.un.org/millenniumgoals/bkgd.shtml. 
Rio+20 UN Conference on SD summoned back the world leaders in 2012 in Rio de Janeiro, but this time with the full participation of civil society. The purpose was to evaluate the progress achieved in the implementation of decisions agreed back in 1992 and to reaffirm the UN members' full commitment to the $\mathrm{SD}$ paradigm. Basically the agreed conclusion was that urgent action is needed in order to achieve SD, to overcome all the remaining gaps, and properly address emerging challenges. The clear and practical SD measures need to be implemented consistently in spirit of justice, equity, inclusiveness, freedom, peace, security, and respect for all human rights and "fundamental freedoms, without distinction of any kind as to race, colour, sex, language, religion, political or other opinions, national or social origin, property, birth, disability or another status." ${ }^{12}$ The process of developing a new set of SDGs was launched. SDGs were built upon the experience of Millennium Development Goals implementation and the strategic vision of the post-2015 agenda was created.

Finally, in 2015, the UN SD Summit was held in New York for the adoption of the post-2015 development agenda. The new 2030 Agenda for SD, was developed under the bravely coined name "Transforming Our World." Agenda 2030 claims to be a plan of action for people, planet, and prosperity which aims to finally shift the whole world onto the path of sustainable resiliency. The international community was summoned one more time around embarking further collective journey, pledging that this time no one will be left behind. The newly shaped set of 17 SDGs and corresponding 169 targets demonstrate humanity's universal ambition on seeking to reach what was not achieved in the global process so far.

Religious leaders from around the world also signed statements in favor of peace, climate justice, or environmental protection. Archbishop Bernardito Auza, Apostolic Nuncio and Permanent Observer of the Holy See to the United Nations, finds the position of the Church within the SDG framework rather clear:

The strength of religions and their cooperation to foster peaceful and inclusive societies essential for development rests on their capacity to raise and nurture prophets and builders who are able to inspire concrete action, develop a rapport of immediacy in individuals and communities, and rally people to work together [in patience and perseverance] for something greater than themselves (Auza 2015, 12).

Its goals are fostering peace and inclusiveness, nurturing and equipping transformational leaders, inspiring concrete actions, developing sense of immediacy, and encouraging cooperation.

12 The document "Future We Want" is available on https://sustainabledevelopment.un.org/index. php?menu=1298. 


\section{Implementation of Sustainable Development Goals}

17 SDGs make the very heart of Agenda 2030. ${ }^{13}$ They represent an urgent call for action carried out in the way of global partnership raised by all countries, either developed, developing, or underdeveloped. All implementers ${ }^{14}$ clearly recognize that ending poverty and other deprivations must comply with actions aiming to improve health and education systems, reduce inequality, and encourage economic growth. While challenges of climate change and working hard to preserve stability, integrity, continuity, and diversity of terrestrial and water ecosystems and their services are consistently being tackled. Moreover, the community's work becomes more and more important. It is about "practicing the neighborly disciplines, to celebrate the secular sacraments of neighbourliness" (Block et al 2016, 63).

For the purpose of this research, three specific SDGs were selected to be considered closer in the light of the Kingdom of God concept and principles, particularly about the Kingdom's capacity to create and sustain well-being for the people and the whole of creation.

Table 1. 17 SDGs

\begin{tabular}{|l|l|}
\hline No. & SDG \\
\hline 1 & End poverty in all its forms everywhere \\
\hline 2 & $\begin{array}{l}\text { End hunger, achieve food security and improved nutrition and promote susta- } \\
\text { inable agriculture }\end{array}$ \\
\hline 3 & Ensure healthy lives and promote well-being for all at all ages \\
\hline 4 & $\begin{array}{l}\text { Ensure inclusive and equitable quality education and promote lifelong learning } \\
\text { opportunities for all }\end{array}$ \\
\hline 5 & Achieve gender equality and empower all women and girls \\
\hline 6 & Ensure availability and sustainable management of water and sanitation for all \\
\hline 7 & Ensure access to affordable, reliable, sustainable, and modern energy for all \\
\hline 8 & $\begin{array}{l}\text { Promote sustained, inclusive and sustainable economic growth, full and pro- } \\
\text { ductive employment and decent work for all }\end{array}$ \\
\hline 9 & $\begin{array}{l}\text { Build resilient infrastructure, promote inclusive and sustainable industrializati- } \\
\text { on and foster innovation }\end{array}$ \\
\hline
\end{tabular}

13 See: https://sustainabledevelopment.un.org/?menu=1300.

14 See: https://sustainabledevelopment.un.org/memberstates. 


\begin{tabular}{|c|c|}
\hline 10 & Reduce inequality within and among countries \\
\hline 11 & Make cities and human settlements inclusive, safe, resilient, and sustainable \\
\hline 12 & Ensure sustainable consumption and production patterns \\
\hline 13 & Take urgent action to combat climate change and its impacts \\
\hline 14 & Conserve and sustainably use oceans, seas, and marine resources for SD \\
\hline 15 & $\begin{array}{l}\text { Protect, restore and promote sustainable use of terrestrial ecosystems, sustaina- } \\
\text { bly manage forests, combat desertification, and halt and reverse land degrada- } \\
\text { tion and halt biodiversity loss }\end{array}$ \\
\hline 16 & $\begin{array}{l}\text { Promote peaceful and inclusive societies for SD, provide access to justice for all } \\
\text { and build effective, accountable and inclusive institutions at all levels }\end{array}$ \\
\hline 17 & $\begin{array}{l}\text { Strengthen the means of implementation and revitalize the global partnership } \\
\text { for SD }\end{array}$ \\
\hline
\end{tabular}

Within the context of ensuring healthy lives and promoting well-being for all at all ages (SDG 3), despite the fact that the health of millions of people has been greatly improved especially in the sense of increasing life expectancy, reducing maternal and child mortality, and fighting against diseases transferred through immediate contact, still there is a growing sense of progress not happening fast enough. Moreover, new issues immerge continuously especially related to mental health and decreasing antiviral and antimicrobial resistance.

It seems that the health of the world population becomes even more vulnerable with increased mobility. Although greater mobility can be seen as a privilege, it opens up possibilities for spreading highly infective viruses among world populations. Many national health systems, even in developed countries, are experiencing great challenges in adjusting properly to new health circumstances especially in the sense of channelling massive movements and gatherings. Therefore, according to the SD paradigm, health and a healthy life do not necessarily anticipate greater availability of products and services. Health is more about realistic expectations and a moderate life-style that honors and enjoys the genuine simplicity of well-nurtured relationships and mutual encouragement.

Within the context of making cities and human settlements inclusive, safe, resilient, and sustainable (SDG 11) although introducing/encouraging clean energy sources and transportation means, green economy, smart and green housing, decreasing the ecological footprint, access to nature and open space, locally produced food, etc., seems like the right strategy but they are still not available to many. Good city governance presupposes dedicated transformational leadership and the ability to bring people of great vision to work together. It also takes profo- 
und ethics of the commons and progressively resistant perseverance. The church can certainly position itself within this framework and offer a wide spectre of practical skills (e.g. community organizing, project developing, fundraising, encouraging interdisciplinary approach in solving problems) working directly with the homeless and other marginalized social groups.

Within the context of protecting, restoring, and promoting sustainable use of terrestrial ecosystems that includes sustainable forest management, combating desertification, reversing land degradation, and halting biodiversity loss (SDG 15), the capacity for the harmonious coexistence of man and nature seems to be increasingly diminishing, especially through fostering a mentality focused on social recognition and visible success greatly supported by commodities. Environmental and natural protection issues are traditionally tackled on the margins of social discourse and, too often, only for populistic purposes. Although the church traditionally does not see the nature protection and resource management as its priority, it can become intentional about promoting principles of long-term sustainability among people in many different ways. Such as the wise use of water and energy, prioritizing local products and services, avoiding non-reusable but eco-friendly things and materials, teaching kids to be environmentally sensitive, local community environmental awareness-raising, etc. Although forest loss rate is slowing down, more key biodiversity areas are being protected, and more financial resources are becoming available for biodiversity protection, still land degradation continues irreversibly, biodiversity is occurring at an alarming rate, invasive species corrupt ecosystem resilience, and wildlife poaching continues despite the enforced legislation.

Planning and action for the SD takes thinking and working beyond conventional boundaries. Interdisciplinary collaboration is crucial. People need to be able to hear others and to understand and appreciate otherness. However, the local knowledge of the social and technical context is also very important. It is valuable to consider different analytical perspectives (political economy, political ecology, institutional, common property, governance, etc.) and to understand the relationship(s) between poverty and the environment in creating a common understanding and realizing meaningful and doable way further. ${ }^{15}$

15 For the valuable insight in the process dynamics, look for the experience of different study groups within Development Studies Association (DSA) on https://www.devstud.org.uk/. 


\section{Discussion}

Although it can be confusing that the most important words in Jesus' vocabulary cannot be explicitly found in the Old Testament, the statistic is deceptive in this particular case. ${ }^{16}$ God as the one who reigns and scatters evil is the main character of all the Psalms and other Old Testament texts and there are countless references to God acting and ruling as a king. Sigurd Griendheim $(2018,16)$ notes that this concept portrays, "God who offers and shares a life of wealth, abundance, and quality relationships with other people. God provides life without shame, conflict, jealousy, envy, competitiveness, humiliation." This is the background for modern Christians becoming more convinced about the Kingdom's creative power that profoundly affect and shape our reality. Though, we also need to agree with Dean Flemming in being careful "not to impose New Testament on the Old Testament, or even more, a modern missionary model in which mission is limited to explicitly preaching the gospel to the nations" (Flemming 2013, 46).

We live in a time of constant change, often in circumstances of fear and painful uncertainty. New ideas continuously challenge old institutions and threaten old structures that are cracking and crumbling before our eyes. As John Blewitt notes, conventional boundaries are disappearing practically in all sectors of human life and production, and traditional authorities are becoming less and less clear and relevant. In a world where partnership and cooperation become a necessity, Blewitt is sure that any kind of isolation simply cannot be afforded (Blewitt 2008, 431). Destructive behaviors, sheer desperation, and uncontrolled violence are tightly interconnected with our lives, and it was the same for our spiritual ancestors. We are often rightly confused about what is real and what is not. In that sense, Richard S. Hanson (1971, 11-12) is still consistently relevant when he claims that our capacity of discerning and distinguishing between crucial and insignificant, between permanent and temporal, between precious and trite, is progressively diminishing.

We have a desperate need to discover what can really help us to live and thrive. In that sense, we will further try to summarize on bringing two concepts together. First, we will demonstrate how the Kingdom of God and SD function in synergy, and then we will try to point on their crucial discrepancies. We will also take the opportunity to emphasize the importance of the right kind of leadership - cruciform leadership compassionately anticipating progressive personal, social, political, and economic transformation. Finally, we will conclude the chapter by discussing the opportunities to apply newly gained perspective by/in the church.

16 There are only two Old Testament references to the Kingdom of the Lord: 1 Chronicles 28:5 and 2 Chronicles 13:8 (NRSV). 


\section{Synergies}

Two concepts closely considered in this research, the Kingdom of God and the SD, although coming from different sources they seem to tackle the same set of universally relevant issues with almost a similar level of enthusiasm. In the context of their practical application, both are trying to understand the present moment of humanity and human civilization rightly, especially within the light of relevant historical experience and the possible future perspectives.

Based on seventeen Isaiah's passages, Glen Stassen and David Gushee (2003, 25) recognize seven crucial marks of God's reign: 1. deliverance or salvation, 2. righteousness/justice, 3. peace, 4. joy, 5. God's presence as Spirit or Light, 6. healing, 7. return from exile. This is tightly interconnected to the Agenda 2030 of the world that tries hard to get back its deeply compromised well-being. Moreover, in Romans 14:17, Paul is also deriving from Isaiah about the Kingdom of God; righteousness, peace, and joy in the Holy Spirit. Matthew talks about feeding the hungry, welcoming the stranger, visiting the sick, paying attention to the children (19:14), forgiving debts (18:23-35), peace-making and welcoming outcasts (19:12), healing (19:28), but also being joyful in the presence of the Bridegroom (13:34). The SD paradigm also claims its basic principles to be justice, peace, equity, social stability, security, prosperity, economic growth, and social inclusiveness.

Both concepts struggle with a proper understanding of the need for longterm resiliency and adaptability. In addition, both share a high appreciation for the communal effort and meaningful partnerships. In that sense, Israel's experience of exile that forced people to reconsider their priorities in order to survive and thrive is an important lesson to learn. On the other hand, studies showing that loss of resilience, caused by irresponsible behavior, indubitably pave the way to catastrophic shifts in major ecosystems and their services, raise serious public awareness, and focus social interest more on environmental matters (Scheffer 2001, 592). The same principle applies to the Kingdom of God since long-term resilience is understood as tightly interconnected to covenantal faithfulness. Although policy decisions are relying mainly on scientific evidence and economic arguments, both being politically and publicly attractive since they are quantifiable and comparable, they can easily yield false and oversimplified solutions if not taking the right kind of ethics into account (Peepre and Jickling 1994, 14).

Both thinking and believing systems anticipate the necessity for a sound holistic approach to the management of natural, economic, and social resources. Both concepts encourage creativity, innovation, and "thinking outside the box" attitude, although they employ rather different languages. If we would like to contextualize the Kingdom of God into the contemporary world, the whole SD framework idea would seem rather meaningful to us by being socially progressive, 
by affirming bio-centric ethics, by claiming to be aniconic, and ready to expose and dismantle prejudices. What the SD paradigm seems to be missing in order to be fully effective is a divine sparkle or the presence of the Bridegroom in the midst of sharing the common vision of the present and the future for God's creation in its totality. This divine sparkle is presented through the consistent affirmation of the gifts of the Spirit (Rom. 12, 1 Cor. 12, Eph. 4, and 1 Pet. 4), the unchanging set of universal values that do not alter only because the world needs to reconsider its priorities due to the change of circumstances. This divine sparkle, that proved so many times to have a capacity to bring creative fire into the human sphere, actually ensures sustainability. This divine sparkle that is coming from and is generated by the Kingdom of God is all about sustainability that is obviously not only about economic development. In that sense, Brueggemann lobbies for a fresh perspective on keeping Sabbath as an alternative to the "normative" social behavior (Bruggemann 2018, 223). Without capacity to consider and employ fresh perspectives that challenge dominant social norms, the development itself loses the chance to be universally relevant, fair, ethical, efficient, and inclusive. Without it, the entire developed world progresses fast into a doom by dragging others of lesser capacity to survive and thrive into the same misfortunate destiny.

Encouraging bold imagination profoundly marks both concepts. Old Testament prophets and blue economy ${ }^{17}$ practitioners stand in this context side-by-side as beacons. The words of Andreas Hernandez (2018, 168-169) about the need to reimagine our spirituality and religion in encouraging social movement practices and the emergence of new stories and worldviews in the process of constructing new politics and economics raise many meaningful echoes.

\section{Discrepancies}

The two concepts certainly overlap and presuppose many crucial synergies, but they also include some serious discrepancies. Agenda 2030 promotes health and well-being in a very practical sense and prevention measures appear to be the most meaningful way to tackle the wide scale of damaging human behaviours. However, it needs to be kept in mind that these behaviors are mostly indicators of debilitating life circumstances and deeply corrupted individual and communal relationships that cannot be efficiently healed without a growing sense of acceptance on the general and individual scale, as well as profound reconciliation between different social groups. Richard Clugson's $(2015,35)$ wise prioritizing insight is particularly useful: "Our ethical/spiritual sustainability lenses have us

17 The Blue Economy: 10 years - 100 innovations - 100 million jobs book written by Gunter Pauli and published back in 2010 brings many inspiring little business models that shift society from scarcity to abundance by taking what is locally available while tackling issues that cause environmental and related problems in new ways. 
approach SDGs from a conception of the good life in which economic growth and providing a wide array of consumer choices is good if [and only if] it enables the fullness of life." However, SDG-s 4, 5, and 10 deal with reducing inequalities (gender, education, and countries), inequalities generated by economic, ethnic, language, religion, lifestyle, and other social differences do not seem to be really tackled.

Jesus' words recorded in Matthew 4:4 "One does not live by bread alone, but by every word that comes from the mouth of God" (NRSV) desperately emphasizes the universal problem of human individuals and communities striving to be self-sufficient. We keep forgetting there is much more beyond mere economical security and exclusive understanding of life dynamics and system of priorities which does not take God and neighbour(s) seriously into account. The universal human need to ensure cosy comfort and convenience often makes us lack a broader perspective on reality. In that context, we need to be aware of the fact we already made a lot of lethal mistakes, so the broad public repentance could bring profound healing. The Bible tells a lot about this helpful method of social reconciliation as a prerequisite of well-being, but the world is still resentfully hesitating about taking over the full responsibility.

We can learn a lot today from the history of the socio-economic experience of ancient Israel. The socio-political elites who were located in the capital cities of Samaria and Jerusalem administered its small $8^{\text {th }}$ century BC economy. These urban elites extracted wealth from the peasant farmers through the system of taxation and high-interest land loans. Though the arrangement was exploitative, it appeared to be perfectly normal and safe in its perpetuity. Until, as Brueggemann $(2018,199)$ sharply notes, somehow, inexplicably, a series of unconnected poets dared to disrupt the entire "normative" economy. They were declaring the emancipatory God who is closely interested in the political economy. They were inviting for the whole economic system to be reimagined and reconfigured for the sake of covenantal responsibility to God (Brueggemann 2018, 205). In the midst of inconvenient and scary historical context, Old Testament prophets were calling aloud for justice and holiness. They were calling for Thy Kingdom Come. As Brueggemann notes, they were putting their fingers on an inconvenient therefore(s). The same therefore(s) that the modern world still wrestles with, therefore that resonates even louder today because of the availability of respective historical lessons and elaborated scientific knowledge. We are facing the consequences of the same cynical exploitation that was happening consistently already for three millennia.

Virtues of the Kingdom people seem rather strange in the midst of a contemporary secular mentality, which is mostly characterized by pride, greed, search for outward success, and self-righteousness. Human freedoms are institutionally 
protected today and rules of social behavior are being imposed by laws. As a famous Croatian sociologist professor Ivan Cifrić claims, modern society thus practically abolishes ethos and replaces it with various forms of institutional and/ or instrumental system of responsibility (Matijević 2015, 146). From the other side, Kingdom people, powerfully named by the prophet Isaiah "oaks of righteousness" (Isaiah 61:3), are scandalously different in their ethics. They are "poor in spirit" so they eagerly strive for more of the Spirit; they are mournfully aware of all relationships, opportunities, resources, and kairos-es (Greek kaıpós) lost due to the ignorance, negligence, or mismanagement; they are humble and meek by not being self-consumed. Kingdom people hunger and thirst for righteousness, they are merciful, compassionate, and patient because they seek God with holistic integrity. They are peacemakers who are even ready to suffer for and with the oppressed, marginalized, and broken-hearted.

\section{The issue of leadership}

The Bible affirms that land (and the same applies to all natural resources, renewable and non-renewable) should be managed in a life-giving way. However, this invitation requires all kinds of breaks and departures since God's promise of fertility, multiplication, and well-being keeps inviting us to dynamically rethink and reshape our economy (Brueggemann 2002, 191, 196). The basic trait of the transformational leader is an openness to be dynamically challenged and changed or, in Biblical language, moulded by God (Is. 64:8; Jer. 18:1-11; Rom. 9:21; 2 Cor. 4:7) and by immediate cries of his or her neighbors.

Jesus' proclamation of the Kingdom was not disconnected from the cultural and political issues of his time, but they are intimately and inextricably related. As Marcus Borg (1998, 270-271) says, the connection was not simply negative challenge and criticism, but also positive in a sense of Jesus' passionate involvement in the corporate life of people, Jesus was proclaiming and compassionately anticipating personal, social, political, and economic transformation. The underlying problem with the SD paradigm might be a rather lukewarm dominant attitude towards the need for (radical) social change and is mostly represented by the lack of transformational leadership.

\section{Participating in God's Mission}

Christianity is intrinsically missional since God is on the mission of reconciling the whole created order to himself. Through his mission, God is saying a powerful "YES!" and, at the same time, a determined "NO!" to the world. Actually, the whole Bible itself is a missional phenomenon (Wright 2013, 22). Nevertheless, Daniel Bosch $(2011,8-11)$ points to a few basic New Testament models of mission: Matthew's making and sending disciples, Luke's practice of forgiveness and solidarity, and Paul's invitation to join the eschatological community. 
All models are profoundly driven by the immediate socio-political context of the receiving audience. Bosch claims that different models of mission develops different theologies of mission, but they do not necessarily exclude each other, although they are frequently at odds.

The mission of the Church is to participate in God's own mission. God and his creation are in a constant dynamic relationship and we are expected to honour but not to worship the created order. So considering the earth resources, we could agree with Christopher Wright $(2013,397)$ that we are in a landlord-tenant relationship with God and we are held accountable for how we treat his property. Our treatment of the earth reflects our own relationship with the Creator, thus we are not neutral when we commodify and commercialize, use and abuse natural resources for our own benefit. In that sense, our mission is "an authorized activity carried out as tenants on the instructions of the owner of the property" (Wright 2013, 404). So, according to Wright, the simple biblical affirmation "The earth is LORD's" is a non-negotiable platform for both ecological ethics and missional confidence.

Dean Flemming $(2013,23)$ invites us to realize that mission is much more than winning people to Christ. It is about demonstrating justice and mercy in a society that does not know Christ. The mission begins (and ends) with God and the mission of God's people is to participate in the full mission of God. The intersections between the SD and the Kingdom of God create clear opportunities for the church to immerse herself deeply in practicing shalom, nurturing hesed, and participating the world processes without losing her genuine identity by encouraging inclusiveness, lobbying for social justice, carrying for the poor and marginalized, and extending love and compassion onto the whole creation.

\section{Conclusion}

The two concepts considered in this research, the Kingdom of God and SD, were never supposed to be separated. Although coming from different sources, they apparently tackle the same set of universally relevant issues. They are obviously coming from different eras, use different languages and vocabulary, and spring out from different socio-political contexts. Nevertheless, both are eagerly anticipated, their fulfilment is of utmost and urgent importance, and they both call for profound personal and communal transformation. Both are powerfully creative and innovative and have the capacity to enthusiastically mobilize communities, peoples, nations, and resources.

The Kingdom of God is primarily about deliverance from the dominion of sin, shame, and guilt, about having clear prospects for salvation, about the affirmation of righteousness and justice for everybody, about ensuring peace and joy 
in God's immediate presence, and about experiencing a healing and liberating "return from exile." It is expressed through various activities like feeding the hungry, welcoming the stranger, visiting the sick, paying attention to the children and other marginalized groups, forgiving debts, peace-making, welcoming outcasts, holistic healing, and enjoying intimacy with Jesus that brings profound, visible, and life-giving success. The SD paradigm claims also its basic principles to be justice, peace, equity, social stability, security, prosperity, sound economic growth, and social inclusiveness.

However, both concepts struggle with providing a proper understanding of the need for long-term resiliency and adaptability and share a high appreciation for the communal effort and meaningful partnerships. Both anticipate the necessity for sound holistic management of natural, economic, and social resources, and both concepts encourage the attitude of being progressive, creative, and innovative.

The Kingdom of God is dynamically performative. God performs and we actively participate by adopting new lifestyles of meaningful servanthood and humility while taking care of outcasts and loving our enemies. We constantly need to remind ourselves that "Jesus fulfilled Israel's age-old hope, but not in the way anybody expected or wanted" (Wright 2014, 182). In the same paradoxical sense, the SD paradigm yearns to be adaptive and sensitive to the growing needs of all social groups by nurturing the culture of compassion and inclusion.

A similar set of virtues are promoted by both concepts, although virtues of the Kingdom people can seem rather strange if observed through the lenses of a dominant contemporary mentality. Self-righteousness can be found among humans of all times, the modern world mentality sharply opposes the ethics and the life-style of the Kingdom.

The Kingdom is about eagerly striving for being transformatively led by the Holy Spirit; about being mournfully aware of all relationships, resources, and opportunities that are lost; about being meek and humble due to having an insight into the larger and deeper reality; about being hungry and thirsty for righteousness; about being merciful, compassionate, and patient because of the holistic personal and communal integrity; about being peacemakers willing to understand and share the experience of the oppressed, marginalized, and broken-hearted; about willingness to reconsider "normative" social behaviors. We are expected to put Jesus' words into actions and thus participate in God's reign on earth and among humans. In that sense, the church certainly cannot afford to isolate herself from the so-called secular world.

Within the SD framework, the role of the church is to make sure that nobody is left behind. Nevertheless, the church also needs to work diligently in expanding normative thinking, especially when dealing with such complex and multi- 
dimensional problems like poverty, ${ }^{18}$ human health, or environment protection/ management. Jesus was doing the same. Although the experience of the world's fight against the COVID-19 pandemic might force different communities of the world to reconsider their priorities and create new ways of dealing with their sustainability, the church will still rightly insist on the very same set of Kingdom values: love, compassion, truth, justice, and hope for the final reconciliation.

\section{Bibliography}

Allison, Dale C. Jr. 2010. Constructing Jesus. Memory, Imagination, and History. Grand Rapids: Baker Academic.

Auza, Bernardito. 2015. "Religion and the Sustainable Development Goals." Dialogue \& Alliance 29 (1): 10-13.

Barram, Michael. 2007. "The Bible, Mission, and Social Location: Toward a Missional Hermeneutic." Interpretation 61 (1): 42-58.

Blewitt, John. 2008. Understanding Sustainable Development. Abingdon: Earthscan.

Block, Peter, Walter Brueggemann, and John McKnight. 2016. An Other Kingdom: Departing the Consumer Culture. Hoboken, New Jersey: Wiley.

Borg, Markus J. 1998. Conflict, Holiness, and Politics in the Teachings of Jesus. London, New York: Continuum.

Bosch, Daniel. 2011. Transforming Mission - Paradigm Shifts in Theology of Missions. Special Edition. New York: Orbis Books.

Brueggemann, Walter. 2018. Tenacious Solidarity. Minneapolis: Fortress Press.

Brueggemann, Walter. 2002. The Land. Place as Gift, Promise, and Challenge in Biblical Faith. Minneapolis: Fortress Press.

Chilton, Bruce. 1984. The Kingdom of God in the teaching of Jesus. Philadelphia/ London: Fortress Press.

Clugston, Richard M. 2015. "Religion and the Sustainable Development Goals." Dialogue \& Alliance 29 (1): 31-38.

Dodd, Charles H. 1961. The Parables of the Kingdom. New York: Charles Scribner's Sons.

Dulling, Dennis C. 1992. "Kingdom of God/Heaven." In The Anchor Bible Dictionary, edited by David N. Freedman. New York, London, Toronto, Sydney, and Auckland: Doubleday, 4931-4959.

18 See International Institute for Sustainable Development on https://sdg.iisd.org/commentary/ guest-articles $/$ ?selected $=517$. 
Flemming, Dean. 2013. Recovering the Full Mission of God. Downers Grove: InterVarsity Press.

Gorman, Michael J. 2016. Becoming the Gospel: Paul, Participation, and Mission. Ch. 5. Grand Rapids: Eerdmans.

Green, Joel B. 2013. "Kingdom of God/Heaven." In Dictionary of Jesus and the Gospels, edited by Joel B. Green. Downers Grove: InterVarsity Press, 65636576.

Grindheim, Sigurd. 2018. Living in the Kingdom of God. Grand Rapids: Baker Academic.

Hanson, Richard S. 1971. Kingdoms of man and the kingdom of God. Minneapolis: Augsburg Pub. House.

Hernandez, Andreas. 2018. "Another Worldview Is Possible: Grassroots Social Movements and the 'Great Work." Journal for the Study of Religion, Nature and Culture 12 (2): 147-171.

Matijević, Dalija. 2015. "Ethics of Institutional Nature Protection in Croatia." Social Ecology: Journal for Environmental Thought and Sociological Research 24 (2-3): 145-172.

Peepre, Juri, and Bob Jickling, eds. 1994. Northern Protected Areas and Wilderness. Proceedings from a forum on northern protected areas and wilderness Whitehorse, Yukon November, 1993. Whitehorse: Canadian Parks and Wilderness Society and Yukon College.

Perrin, Nicholas. 2019. The Kingdom of God: A Biblical Theology. Grand Rapids: Zondervan Academic.

Powell, Mark A. 2011. HarperCollins Bible Dictionary. Revised and Updated, New York: HarperOne.

Scheffer, Marten, Steve Carpenter, Jonathan A. Foley, Carl Folke, and Brian Walker. 2001. "Catastrophic Shifts in Ecosystems." Nature 413: 591-596.

Stassen, Glen H. and David P. Gushee. 2003. Kingdom Ethics: Following Jesus in contemporary context. Downers Grove: InterVarsity Press.

Treat, Jeremy R. 2019. Seek First: How the Kingdom of God Changes Everything. Grand Rapids: Zondervan.

Wright, Christopher J. H. 2013. The Mission of God: Unlocking the Bible's Grand Narrative. Downers Grove: InterVarsity Press.

Wright, Nicholas T. 2014. Surprised by Scripture. Engaging Contemporary Issues. New York: HarperOne. 
Dalia Matijević

\title{
Koncept održivog razvoja kroz prizmu Božjeg kraljevstva
}

\begin{abstract}
Sažetak
Istražujući poveznice između dva naizgled inkompatibilna koncepta, Božjeg kraljevstva i održivog razvoja, pokušat ćemo ih promotriti paralelno, a dobivene rezultate iskoristiti tako da uvidimo mogu li se ova dva koncepta međusobno podržavati. Cilj nam je bolje razumjeti buduće perspektive koje se otvaraju pred Crkvom u suvremenom kontekstu. Dva, ovdje razmatrana koncepta nikad nisu niti trebala biti razdvojena. Iako dolaze iz različitih izvora, koriste drugačiji izričaj te izrastaju iz dva vrlo različita sociopolitička konteksta, oni se ipak bave istim univerzalno važnim pitanjima. Za oba koncepta vrijedi da se željno iščekuje njihovo ostvarenje, oba su od ključne važnosti, oba pozivaju na duboku osobnu i kolektivnu transformaciju, oba pretpostavljaju snažnu afirmaciju kreativnosti i inovativnosti, oba predmnijevaju značajan kapacitet mobiliziranja zajednica, ljudi i dobara. Preklapanja između održivog razvoja i Božjeg kraljevstva omogućavaju Crkvi da u svijetu praktično primjenjuje shalom i njeguje hesed, potičući i razvijajući duh prihvaćanja drugog, dosljedno lobirajući za socijalnu pravednost, brinući se o siromašnima i marginaliziranima te šireći ljubav i suosjećanje na Božje stvorenje u cjelini, ne ovaj put bez gubljenja svoga izvornog identiteta. U kontekstu praktične primjene načela održivog razvoja, uloga je Crkve osigurati da nitko ne bude izostavljen ili zanemaren. Crkva bi, zapravo, mogla biti najbolji dio prakse održivog razvoja, upravo svojim upornim inzistiranjem na istom skupu univerzalnih vrijednosti Božjeg kraljevstva, bez obzira na to kako se mijenjaju okolnosti.
\end{abstract}

